\section{Heidelberg and Academic Freedom}

Translations of extracts of speeches made at the ceremonial dedication of the Philipp-Lenard-Institut at Heidelberg in December last were given in an article in NatuRE of January 18, p. 93. The speech made by Prof. J. Stark, president of the PhysikalischTechnische Reichsanstalt and of the Deutsche Forschungsgemeinschaft, is published in full in the February issue of Nationalsozialistische Monatshefte. This journal, edited by the "Reichsleiter für weltanschauliche Schulung", Alfred Rosenberg, is intended to be the leading periodical for German intellectual and academic circles. Prof. Stark's speech expresses even more extreme views than were represented in the extract given in Nature. It appears from a letter published this week in our correspondence columns that $1935-36$ is not really the 550th anniversary of the University of Heidelberg, but the 549th. The facts as stated by our correspondent have been verified by reference to original sources at the British Museum. It has seemed curious to many of us that the University should have arranged for a half-century celebration, but it is even more strange that the 549th anniversary should have been chosen for it. No news has reached us officially from scientific societies or universities as to whether they propose to send delegates or not, or merely to present addresses. Announcement has been made, however, in the public Press, that the senate of the University of Birmingham has unanimously decided not to accept the invitation. The Universities of Oxford and Cambridge will also probably decline to send representatives. The Cambridge branch of the Association of Scientific Workers has sent to NATURE a letter, in the course of which it is urged that "a refusal to send representatives must not be interpreted as an affront to the University of Heidelberg, but as an indication that scientific opinion in Great Britain condemns the atmosphere in which members of that University are compelled to work".

\section{Mr. H. G. Wells's Film "Things to Come"}

Mr. H. G. WeLLS is the only man of letters who understands the scientific spirit, and has consistently urged the use of it in the solution of social problems. In his imaginative romances, as well as in works on social, religious and political questions, he has always presented science as a progressive influence and has remonstrated against the unworthy ends for which it is often used. The hope expressed in his "Anticipations" and "A Modern Utopia" took different form in "The Shape of Things to Come" published two years ago and was accompanied by a warning of disaster unless human purposes were determined by reconstructed principles. Science has put into the hands of civilised man the power to destroy himself or to make the world a celestial dwelling place; and the sooner this is widely realised the safer will the world be for humanity. There is no better way to-day of making this message universal than through the motion picture; and this is done in the marvellous film "Things to Come", the world première of which was given in London on Friday,
February 21. The film has been produced by Mr. Alexander Korda ; and Mr. Wells, whose scenario of it was noticed in NATURE of January 11 last, has taken an active part in the production of the picture.

THE general story is that of the destruction of the civilised world by war-fever and pestilence, and after almost every material structure had been destroyed and intellectual culture had been lost, a new world government arises in which scientific leaders have control. Through the three generations represented in the film, some basic human attributes remain unchanged, and they are represented by Dr. Harding's devotion to medical research even when the world is in ruins; Cabal, who never falters in his confidence in the power of science to promote human welfare; the military autocrat, who regards gladiatorial conflicts as the only means of securing peace ; his mistress, Roscana, with the eternal 'sex appeal' diverting ethical aims; Theotocopulus, the sculptor who even in a beautiful and regenerate world, raises a revolt against mechanisation and looks with longing to the Golden Age of the past; and finally the two young people who, still with the spirit of adventure in them, start for a journey around the moon in spite of all efforts of reactionaries to restrain them. It is scarcely within our province to comment upon the technique of this remarkable production, but we have no hesitation in saying that every moment and movement of the picture has a meaning and that the film stands as high above the usual sentimental stock of the picture house as a triumph of creative art does above a gaudy advertisement or a classical literary work is superior to a 'penny dreadful'.

\section{The Lumiere Celebration in London}

WHILE the credit of inventing cinematography rightly goes to W. Friese Green, whose patent, obtained in 1889 , covered the production of a perfect sequence of photographic images on a band of celluloid film taken by one camera with one lens and from one point of view, it remained to the brothers Lumière to invent the cinematographe and to show moving pictures to the public. In December 1895, Louis Lumière gave his first exhibition in Paris (see NATuRE, Nov. 16, 1935, p. 803) and the new invention was introduced to British audiences through the enterprise of the Polytechnic in Regent Street on February 20, 1896. Figures given by Mr. Simon Rowson at a recent meeting of the Royal Statistical Society show how important is the position now held by the cinema in the social life of the country. In 1934, 957,000,000 people in the United Kingdom paid $£ 40,950,000$ to see moving pictures.

TyPICAL of the change which has come about and of the present status of the industry is the fact that the Polytechnic, which was the scene of the first exhibition, now possesses a School of Kinematography where students receive technical training in all branches of the industry. To honour M. Lumière, a celebration was held in the Polytechnic on February 20, the fortieth anniversary of the date on which his 